This article was downloaded by: [University of Toronto Libraries]

On: 05 J anuary 2015, At: 04:59

Publisher: Routledge

Informa Ltd Registered in England and Wales Registered Number: 1072954

Registered office: Mortimer House, 37-41 Mortimer Street, London W1T

3J H, UK

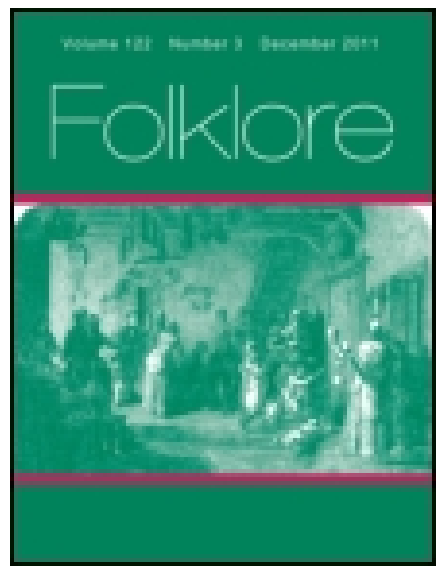

\title{
Folklore
}

Publication details, including instructions for authors and subscription information:

http:// www. tandfonline.com/loi/ rfol20

\section{Folk Traditions of the Mughal Emperors}

Karim Haidar Lodi

Published online: 14 Feb 2012.

To cite this article: Karim Haidar Lodi (1907) Folk Traditions of the Mughal Emperors, Folklore, 18:4, 427-432, DOI: 10.1080/ 0015587X.1907.9719796

To link to this article: http:// dx. doi. org/ 10.1080/0015587X.1907.9719796

\section{PLEASE SCROLL DOWN FOR ARTICLE}

Taylor \& Francis makes every effort to ensure the accuracy of all the information (the "Content") contained in the publications on our platform. However, Taylor \& Francis, our agents, and our licensors make no representations or warranties whatsoever as to the accuracy, completeness, or suitability for any purpose of the Content. Any opinions and views expressed in this publication are the opinions and views of the authors, and are not the views of or endorsed by Taylor \& Francis. The accuracy of the Content should not be relied upon and should be independently verified with primary sources of information. Taylor and Francis shall not be liable for any losses, actions, claims, proceedings, demands, costs, expenses, damages, and other liabilities whatsoever or howsoever caused arising directly or indirectly in connection with, in relation to or arising out of the use of the Content.

This article may be used for research, teaching, and private study purposes. Any substantial or systematic reproduction, redistribution, reselling, loan, sub-licensing, systematic supply, or distribution in any form to anyone is 
expressly forbidden. Terms $\&$ Conditions of access and use can be found at http://www.tandfonline.com/page/terms-and-conditions 
order to induce them to steal rice from the fields of others to plant in their owner's land. Sacrifices are offered to them, and their powers are greatly increased if they have been stolen. (Cf. vol. vi., p. 196.) The figure is 61 inches high, and has the usual vertical hole in the top of the head. It is seated, and perfect, except that the portion of the legs between the knees and feet is missing.

A. R. WRIGHT.

\section{Folk Traditions of the MUghal Emperors. ${ }^{1}$}

THE following tales relating to the Mughal period in India were collected by Muhammad Husain Khãn of the Muhammadan Anglo-Oriental College, Aligarh, in the United Provinces of Agra and Oudh, India, from peasants in the Panjāb. They are very popular among the higher classes. I am not aware whether variants of them are current among the people of other parts of Northern India; but, as far as it has been possible to ascertain, they are found in much the same form throughout the whole of the Panjab.

The Mughal period may be said to commence with the overthrow, in 1526 A.D., of the reigning king, Ibrahim Lodi, by Bābar, a descendant of Genghis Khān and Timūrlang or Tamerlane. On his death in $153^{\circ}$ he was succeeded by his son Humãyan, who was driven for a time from his throne by an adventurer of Afghān descent, Shīr Shāh. On his death in $155^{6}$ the crown passed to his son Akbar, whose long reign of 49 years covers the greatest period of the Mughal Empire. His son Jahāngir was followed in 1628 by Shāh Jahān, to whom we are indebted for some of the finest architectural monuments of his dynasty-the new city of Delhi, the Tãj Mahal at Agra. The reign of his son Aurangzib ( $165^{8-1}$ 707) marks the decadence of the Empire, largely due to the growth of the new Mahratta power in the Deccan.

Karim Haidar Lodi.

${ }^{1}$ With Notes by W. Crooke. 


\section{Tale $I$. The rise of Shirū or Shir Khän.}

Before the birth of a child destined ultimately to rule Northern India, his mother dreamed that the moon had entered her womb. She got up and told the dream to her husband. To her surprise he gave her a sound beating. "I did this," he said, "to prevent you from going to sleep again to-night after such a good dream, lest a bad one may follow it and destroy its effect." One day the child cried to his father to give him a dirham (a coin worth about 5 pence). A darwesh who was passing by said: "What! the future king of India begging for a dirham !" When the boy grew up his mother sent him abroad to seek his fortune. He begged his way to Delhi, and lay down to sleep before the shop of a Hindu merchant. When the merchant came to open his shop in the morning he saw that a cobra was shading the face of the youth. 1 The Banya was impressed by the incident, and used his influence to obtain for the youth a commission in the army, where he rapidly gained distinction. One day in the madness of his pride, the Emperor Humāyūn cried out at a review : "With such an army I could fight God Almighty himself!" Shīr Khān and the other Muhammadans in resent at his impiety called out: "Let the infidels follow the infidel, and the faithful follow us." The army mutinied and elected Shir Khann as their leader. He thus gained the throne, and in his prosperity he did not forget his benefactor, (who was the famous Himū Baqqāl), and allowed him to rule the kingdom for two days with full sovereign powers. ${ }^{2}$

\section{The Wazì of Shāh Jahān.}

In the district of Jhang, in the Panjāb, there was once a peasant whose wife was about to give birth to a child. She longed for an apple, which her husband was unable to procure. Just then a

${ }^{1}$ This is a common incident in Indian folk-lore. See Crooke, Popular Religion and Folk-lore of N. India, 2, ii. 142 : Tennent, Ceylon, i. 389; Bombay Gazetteer, xv. Pt. ii. 331 .

2The account of the mutiny is unhistorical. Shīr Shäh defeated Humãyūn in two battles, in 1539-1540 A.D. Himũ is an historical personage. He rebelled against Akbar, was captured, and executed in 1556. 
caravan from Kanbul passed by, and the peasant asked one of the merchants to give him one. The merchant answered: "Give us an agreement that your son, when he becomes Wazīr, will free us from transit dues." The man, wondering, agreed, and put his mark on the agreement. When the child was born he showed marvellous intelligence. One day he was sleeping near a well in his father's field, when a venerable old man, dressed in green, holding a sceptre in his hand, appeared to him in a vision, and ordered him to go to Delhi and attend a school there. ${ }^{1}$ The dream was repeated three times, and when the boy did not obey the order the old man threatened to break his bones with his sceptre. So the boy went to Delhi, where he soon became proficient in all the sciences. But he was obliged to earn his living as a day-labourer. One day he was working in the Emperor's palace, when Shāh Jahān received a letter from the King of Persia written in such a way that no one could read it. As the Emperor and his attendants passed by the youth saw that the letter could be read only by looking through the sheet from the back. At first he was afraid to interfere; but finally he ventured to address the Emperor. The Emperor at first was angry, but later on he sent for the youth, and ordered that he should be bathed and supplied with a court dress. He advanced in favour, and finally became Wazir. Then he fulflled his father's promise, and remitted the transit dues on the Kabul caravans.

\section{IIJ. How Shäh Jahān appointed his Successor.}

When Shāh Jahăn grew old he decided to select a successor from among his sons. So he ordered his Wazir, Asadulla Khān Asafud-daula, to enquire and report. When the minister visited Dãra, the eldest of the princes, he was treated hospitably, and Dara expressed the greatest devotion to him. Next he went to visit the second prince, Aurangzib, who ordered him to wait at his gate until he had finished his prayers. When he was finally ushered in the prince treated him in an off-hand way and dis-

1 The old man was probably the saint, Khwăja Khizr. Crooke, op. cit. i. 47 f. ; Maclagan, Panjab Census Report, 1891, i. $105 \mathrm{f}$. 
missed him. The youngest son, Murād, made no impression on the Wazir, who, infuenced with the lordly bearing of Aurangzíb, advised the old Emperor to name him as his successor. Shăh Jahãn, however, was in favour of Dāra. The minister, on hearing this decision, begged the Emperor to give him a paper of acquittance, as he knew well that the appointment of Dāra would lead to civil war. The Emperor agreed : Dāra was nominated as his successor. War ensued; Aurangzīb slew his brothers and gained his throne. ${ }^{1}$

\section{Aurangzīb and the Korān.}

When Aurangzīb ascended the throne he placed his father Shāh Jahãn in confinement. Now, Muhammadans believe that if a boy succeeds in learning the Korann by heart his father will enter Paradise. On such an occasion he receives the congratulations of his friends, distributes sweetmeats, and feeds the poor. ${ }^{2}$ While in prison Shäh Jahān learnt that one of the sons of Aurangzib was able to repeat the whole Korãn. So he sent his congratulations, saying that he was now safe to enter Paradise as his son could recite the holy book. Aurangzīb resented the implied sarcasm, and not to be outdone, set to work and soon learned the Korān by heart. Then he sent this message to his father: "Your son has learnt to recite the Korān, and you are now sure of Paradise."

\section{Aurangzib and his Pìr, or spiritual preceptor. ${ }^{\mathrm{s}}$}

After Aurangzib ascended the throne his Pir came to pay him a visit. The Emperor asked him whether he preferred to dine with him or in the public guest-house. The Pîr chose

1 This is a folk-tradition of the intrigues which went on for the succession during the dotage of Shãh Jahän. The best account of the times is that of Manucci, whose Storia do Mlogor has been recently admirably edited by Mr. W. Irvine.

"Such a person is called Hăfiz, "guardian, protector," and is much respected.

" "Pir" means in Persian "elder," and is usually applied in the sense of Murshid, a religious leader, a sort of father confessor. 
to dine with the Emperor, as he expected a choice dinner. But Aurangzib lived in the most simple way, and when dinner was served it consisted of a plain loaf of barley bread, which he shared with his reverend guest. Next day, when the Emperor asked him where he would like to dine, he answered hastily that he would go to the guest-house.

This Pìr was about to marry his daughter; so he asked Aurangzīb to give him a donation. The Emperor, who was very economical in dealing with public money, answered: "I live on what I earn by transcribing the Korān. Here are eleven cowry-shells, ${ }^{1}$ which is all I have at present." The Pir was naturally disappointed, and when he came home put the cowries in a cupboard. When his wife asked him what he had received from the Emperor, he said: "Go to the cupboard and look." When she opened the door, lo! there were eleven splendid pearls.

\section{Aurangzīb and Saint Sarmad.}

Sarmad was a noted wandering Faqiir in the days of Aurangzīb. One day he met a Mulla or Muhammadan priest, who asked him if he could repeat the Musalmãn Confession of Faith. Sarmad professed utter ignorance of it. The Mulla began to teach it to him, and Sarmad got as far as to repeat the first half of the formula_ "There is no deity but God"; but he could not say the latter half- "Further, Muhammad is the Apostle of God." Sarmad was brought before the Emperor, and there also he refused to repeat the second sentence of the Creed. Aurangzīb ordered him to be executed, and as he bared his neck to the sword, he cried: "In whatsoever shape Thou comest I know that thou art He." Still he would not repeat the words dictated by the Emperor: "Muhammad is the Apostle of God." But his head, when it was severed from the trunk, called out: "There is no deity but God; and, further, Muhammad is the Apostle of God." Aurangzib at

${ }^{1}$ Cowry-shells vary in value throughout India. In one secluded part of Central India the quotation was 2880 to the rupee which is now worth Is. 4 d. 
once understood that he himself had omitted the "further" in the formula. As Sarmad died he placed his severed head on his hand and walked away, saying that he would dash it against the walls of the palace of the unjust Emperor. But his Pir met him and warned him not to be rash. The head fell from his hands and he died just before the Great Mosque of Delhi, where he was buried and his tomb stands to this day. ${ }^{1}$

\section{Notes on some Early Ecclesiastical Practices in ARMenia.}

From an ancient source we learn that the Christian clergy in Armenia once dressed themselves in certain skins. Faustus of Byzance, an historian of the first half of the fifth century, relates (bk. vi.) the following of Zavên, who was Catholicos, or head, of the Armenian Church about the year 386:- "He taught all the priests to wear the dress of soldiers. For they abandoned the apostolic rule of the churches, and began to walk after their own imaginings; since the priests no longer wore in compliance with the religious rule the long robe $(=\mathrm{Gr}$. $\pi 0 \delta \eta p \eta s^{\prime}$ ), as was the law originally, but began to have cross-cut garments above the knees. And they adorned their garments with all sorts of broidery, and gave themselves unsuitable airs. And the priests clothed themselves without scruple in the hides of dead (or strangled) wild animals, which was not appropriate. But Zavên dressed himself in galloons and circular lappets fimbriated with ribbons, and wore sableskin and ermine and wolfskin, and threw over his person foxskins; and so arrayed, they went without scruple up to the bema ${ }^{2}$ and sat there."

1 Sarmad is an historical character. He was an Armenian who became mad through love for a Hindu girl, and went about naked. He attached himself to Dāra, eldest son of Aurangzib, who held unorthodox views. Ile was executed by Aurangzib as 2 beretic about 166I A.D. The story of the headless saint walking about is common in Musalmān hagiology.

2.e. the altar in church. 